\title{
A Magyar Mesterséges Táplálási Társaság 2015. évi kongresszusán elhangzó, felkért és bejelentett előadások kivonatai
}

\author{
Mátraháza, 2015. október 15-17. \\ A kongresszus tudományos szervezóje: Dr. Sahin Péter \\ Tudományos információ: Dr. Nagy Béla, Dr. Csapó Zsolt
}

Felkért előadások

\author{
A magyarországi onkológiai betegek táplálásának napi gyakorlata, \\ összehasonlítva az európai gyakorlattal \\ Bodó Gabriella - József Gergely András - Kovács Zsuzsanna \\ Borsod-Abaúj-Zemplén Megyei Kórház és Egyetemi Oktató Kórház, Miskolc
}

\begin{abstract}
A táplálkozás és táplálás a daganatok kialakulásában és terápiájában egyaránt jelentős szerepet játszik. A 2014. évi ESPEN-EPAAC onkológiai betegek táplálására vonatkozó irányelvének közvetlen célja a benne megfogalmazott evidenciák és szakértôi vélemények alkalmazása a daganatos megbetegedések prevenciójával, felmérésével és kezelésével foglalkozó multidiszciplináris teamek, így az egészségügyi ellátórendszer mindennapi munkája során. A magyarországi onkológiai betegek klinikai táplálásának és az európai gyakorlat összehasonlításához hazai szakmai irányelvet vagy átfogó tanulmányt nem találtunk. Így saját intézményünk gyakorlatát vizsgáltuk az ESPEN-EPAAC irányelvben megfogalmazott bizonyítékokon alapuló ajánlások szerint, a daganatos betegek táplálására vonatkozó általános megállapítások mellett különös figyelmet fordítva a betegségspecifikus területekre. Vizsgálati eredményeink megerősítik azt a tényt, hogy Magyarországon sem kérdéses az onkológiai betegek klinikai táplálásának szükségessége, de nem egységes a szakmai ajánlás - akár hazai, akár egyéb európai szerint történik. Mivel bizonyíték van a táplálás sebészetben játszott támogató hatására, kiterjesztettük együttmúködésünket az intézményünk sebészeti osztályára, hogy elősegítsük az operábilis daganatos betegek gyógyulását perioperatív táplálásterápiával. A tanulmányhoz használt szakmai irányelvek és irodalmi adatok alapján az onkológiai betegek klinikai táplálásának gyógyszerészi támogatásához az alábbi pontokban tettünk javaslatot: l. egyénre szabott táplálásterápia felépítése, tápszerválasztás; 2 . egyedi parenteralis táplálás és az otthoni parenteralis táplálás lehetősége; 3. a tumor és az alkalmazott terápiák tápláltsági állapotra gyakorolt kedvezőtlen hatásainak gyógyszeres befolyásolhatósága.
\end{abstract}

\section{Otthoni parenteralis táplálás az Országos Egészségbiztosítási Pénztár adatbázisának tükrében}

Gresz Miklós

Állami Egészségügyi Ellátó Központ, Budapest

A szerző megvizsgálta, hogy az otthoni parenteralis táplálás (OPT) finanszírozásának lehetővé válása óta hány beteg ellátása került finanszírozásra, és az elszámolt eseteknek milyen jellemzői voltak. Legyújtötték az OEP fekvőbetegadatbázisából az összes OPT-vel ellátott eset (OENO 88744), valamint ugyanezen betegek egyéb fekvőbeteg-ellátásait. Ezt követően történt az adatok elemzése. Az OEP adatbázisában 2013 januárja óta 53 taj részére számoltak el 
OPT-t. Az OPT-ben részesülő betegeknél 22 esetben Hickman-katéterezés, 18 esetben centrális vénás katéterezés történt. Egy beteg részére havonta átlagosan 25 táplálást számoltak el. A 9736 táplálásból 6 beteg esetében (összesen 490 táplálást) napi kettőnél többet jelentettek. Ezek esetében a folyamatos táplálás az előző hónapban nem lett finanszírozásra jelentve. 13 fó volt 18 év alatti beteg, a legidősebb pedig 73 éves volt. 2014 decemberében 21 beteg otthoni táplálását jelentették az OEP-nek. Közülük tizenegyen részesültek OPT-ben egy évnél régebben. Hat beteg táplálása 3 hónapon belül indult. Az OPT-ben részesült betegeknél 32 esetben jelentettek vékonybél-reszekciót, 11 esetben ileo- vagy jejunostomát, 12 esetben egyéb vékonybélmütétet. A leggyakoribb fódiagnózis: 1-es típusú rövidbél-szindróma okozta bélelégtelenség, az esetek 46\%-a. Ezek fele 30-39 éves beteg volt, ók teszik ki az összes beteg 25\%-át. Összesen 14 intézmény 21 szervezeti egysége jelentett OPT-t. Ezek közül van kettő, amely csupán egyetlen beavatkozást jelentett a két év során. 29 esetben az OPT kódja nem sorolt OPT-HBCs-be, feltehetően az egyéb feltételek hiánya miatt. A betegek 76\%-át és a táplálási napok 78\%-át a Szent György Kórház, a Szent Imre Kórház és a Semmelweis Egyetem jelentette. Az adatokból látható, hogy a jelenlegi betegszám jelentősen elmarad a nemzetközi statisztikák alapján a populáció nagyságából előre jelzett 100-150 betegtől. A harmadik hónapban már 10 beteg táplálása történt, de két év után is még csak 21 beteg kap ellátást. 2013. január és 2014. december között 65 betegnél jelentettek K908x vagy K912x fódiagnózist. Pedig ez alatt az idő alatt 2580 betegnél készítettek ileo- vagy jejunostomát. Látható, hogy a finanszírozási lehetôség megteremtése után megindult a betegek tervszerü táplálása. Azonban a számok azt mutatják, hogy jelentősen növelni kellene az ellátott betegek számát.

\title{
Modern minimálisan invazív sebészeti eljárások és a perioperatív táplálás
}

\section{Lukovich Péter}

\author{
Semmelweis Egyetem, Általános Orvostudományi Kar, I. Sebészeti Klinika, Budapest
}

A sebészetben 1985-ben az Erich Mühe által végzett első laparoszkópos cholecystectomia paradigmaváltást hozott, és mára a laparoszkópia minden hasi szerv sebészetében teret nyert. A minimálisan invazív technika tápcsatornára gyakorolt hatásai közismertek: a kisebb hasfali sebek miatt a posztoperatív fájdalom csökken, nincs szükség major analgetikum adására, ezért a bélmúködés hamarabb indul meg. Felmerül ezek alapján a kérdés: A laparoszkópos mútét esetén a beteg hamarabb táplálható-e? Kíván-e olyan fokú előkészítést, mint a hagyományos mútét? A bélcsatornát nem érintő mútétek esetén a válasz az utóbbi kérdésre egyértelmú nem. Míg 25 évvel ezelőtt az epehólyag laparotomiából történő eltávolítása előtt a betegek a mútét előtt hashajtást kaptak, és a mûtét után 2-3 napig szilárd ételt nem fogyaszthattak, napjainkban csupán 4 órányi éhezés szükséges a mútét előtt, és 5-6 órával később akár ehetnek is. A gyomor-bél traktus varrata esetén - a varrat védelme érdekében - néhány napig a betegek nem kaphatnak szájon át táplálékot. Ez gyomor- és vékonybélvarrat esetében 2-3 nap, vastagbélvarrat esetén általában 4-5 nap is szokott lenni. A varratelégtelenség súlyos szövődmény, okai között elsőként szerepel a hypalbuminaemia, a hirtelen preoperatív fogyás, a hemodinamikai instabilitás és a bél keringési zavarai. Mindegyik állapot az időben megkezdett és jól megválasztott preoperatív táplálással javítható. A varrógépek alkalmazásával ugyan csökkenthető volt a varratelégtelenség aránya - főleg a mútéttechnikailag nehezen megközelíthető helyeken (nyelőcső és mély rectumvarrat) -, de nem volt megszüntethető. Újabb és újabb technikákkal (például indociánzölddel történő intraoperatív bélkeringés-vizsgálat) próbálják csökkenteni az ilyen jellegű szövődmények esélyét. Napjainkban a „fast track surgery” ugyanúgy paradigma megdöntésére törekszik, mint 25 évvel ezelőtt a laparoszkópos sebészet: minél kevésbé megzavarni a szervezet egyensúlyát: nem kell drén, nem kell szonda és katéter, a beteget már a mútét napján mobilizálni kell. Akár kézi, akár gépi varrás történik, az anastomosis szakítószilárdsága (burst pressure) olyan nagy, hogy nem okozhat anastomosiselégtelenséget a mütét másnapján kezdett táplálás. Az egynapos vastagbélsebészet egyes országokban már nem utópia. A perioperatív táplálással foglalkozó szakembereknek ebben a környezetben kell megtalálniuk azokat a pontokat, amelyekkel betegük tápláltsága javítható, s így a szövődmények aránya is csökkenthető.

\section{Divatdiéták megítélése a dietetikus szemszögéből Nagy Nóra Zsófia}

\author{
Szent Imre Egyetemi Oktatókórház, Budapest
}

Varázslatos csokoládédiéta, 15 kg fogyást ígérő 8 napos álomfogyókúra, avagy csodaturmixok. Csak néhány elmélet, kiragadva a közismert, szupergyors testtömegcsökkentő módszerek közül. Vajon könnyen betarthatók-e a csodadiéták felállított szabályai? Vajon tényleg van jelentős testtömegcsökkentő hatásuk ily rövid idő alatt? Lehetséges-e megtartani az elért testtömeget a diéta abbahagyása után? Egyáltalán lehet-e az életmódunk része a kiválasztott fogyókúra? Kialakulhat-e idővel szövődmény, negatív következmény a divatdiéták szigorú szabályainak betartása miatt? $S$ végül, mit is nevezhetünk divatdiétának? A feltett kérdésekre a választ kutatásommal is igyekeztem alátámasztani, amelyet a Szent Imre Egyetemi Oktatókórház Anyagcsere Központjának Lipid Profilján végeztem. Kérdőíves mód- 
szerekkel 100 fő túlsúlyos vagy elhízott beteg (35 fő férfi, 65 fő nő) testsúlycsökkentő diétás szokását mértem fel (divatfogyókúrák ismertsége és alkalmazása, jelenlegi étkezési szokások feltérképezése). A diéták variabilitásának útvesztőjében fontos személy a dietetikus, aki hiteles információk birtokában segíthet az életmódváltás fontos elemének - a jól összeállított étrend - megtervezésében, hiszen a páciens és a szakember közötti hosszú távú kapcsolat lehet a kulcs az eredményes és tartós testtömegcsökkentéshez.

\title{
Az enteralis (per os) táplálásterápia helye és szerepe cukorbetegek krónikus sebeinek gyógyításában
}

\author{
Rozsos István
}

THÉTA Egészségközpont, Pécs

\begin{abstract}
A krónikus sebek gyógyításához a feltételek biztosítása, a betegek compliance-ének erősítése, a gazdasági elvárásoknak való megfelelés, mind az ellátórendszer terhe. A cukorbetegek klinikai adottságai nehezítő tényezőként jelenik meg. A sebgyógyítás modern szemlélete sem hoz automatikusan zavartalan sebgyógyulást. Gyakran a betegek nem megfelelő táplálkozása, illetve a tápanyagok aránya nem biztosítja a sebgyógyulás szükségleteit. Előadásunkban 33 beteg kórtörténeti összefoglalóját mutatjuk be a 12 hetes kezelési periódusban, 10 betegből álló kontrollcsoporttal egybevetve. Az eredményekből: a 33 betegből 12-nél teljes gyógyulást regisztrálhattunk a korábban legalább 12 hétig nem gyógyuló betegeknél. Csupán a betegek 10\%-ánál nem történt számottevő változás. Gazdaságossági számítások szerint egy $10 \mathrm{~cm}$ átmérő alatti krónikus seb ellátásának kötszerköltsége nem fertőzött seb esetén havonta $26400 \mathrm{Ft}$, ami 12 hétre minimum $79200 \mathrm{Ft}$. A Cubitan tápszer költsége, napi 2 palack fogyasztása esetén, havonta 27300 Ft, a 3 hónapos kezelési időre 81900 Ft. Gazdaságossági szempontból az a tény, hogy a kötszerek esetén 80\%-os az OEP-támogatás, ami annyit jelent, hogy a beteg a kötszerek árából 5280 Ft-ot, míg az OEP 21120 Ft-ot fizet havonta. A kötésrögzítő árából $1560 \mathrm{Ft}$-ot fizet a beteg, 6240 Ft-ot az OEP. A rugalmas pólya költségét illetően 6 hónapra $1995 \mathrm{Ft}$ a betegrész és 7980 az OEP által finanszírozott rész. A tápszer árának 405 Ft-jából a beteg 205 Ft-ot fizet, tehát havonta $12000 \mathrm{Ft}$ az OEP terhe és $12300 \mathrm{Ft}$ a beteg terhe. A gyógyult 12 betegnél 12 hónap ( 1 év) vetületében az előadásban bővebben beszámolok a gazdaságossági hatásokról. Összefoglalva: 1. A Cubitan tápszer alkalmazása az év 3 hónapjában költségcsökkenéssel jár, hiszen a betegek több mint egyharmada meggyógyult. A második évben csak a kompressziós terápia költsége terheli az OEP-et, tehát a megtakarítás 95\%-os. 2. A vizsgálati időszakban teljesen nem gyógyult, de a javult betegek esetén a kötszerköltség felével, és az első évben való meggyógyulás esetén a második évben már a teljes költség megtakarítása számolható. 3. A betegek egyharmada az első évben nem gyógyul, de a seb mérete csökken, tehát a kötszerköltség felével lehet számolni, így a 2 . évben itt is jelentős a megtakarítás.
\end{abstract}

\section{Az antibiotikumok bélflórára gyakorolt hatása és annak vizsgálati lehetősége}

\section{Szabó Dóra}

\author{
Semmelweis Egyetem, Általános Orvostudományi Kar, Orvosi Mikrobiológiai Intézet, Budapest
}

\begin{abstract}
A bélflóra, amely a teljes emberi mikrobiom megközelítőleg 70\%-át adja, döntően a Bacteroidetes és Firmicutes törzsekbe tartozó baktériumokból és kisebb mértékben Proteobacteria és Actinobacteria baktériumokból áll. A bélflóra egyensúlya fontos az egészséghez. Míg az antibiotikumok használata a bakteriális fertőzések kezelésében életmentő, addig túlzott és helytelen használatuk súlyos következményekkel jár. A legtöbb antibiotikum rendkívül destruktív hatású a bélflórára, az érzékeny baktériumok - Escherichia coli és a barrier funkcióért felelős anaerob baktériumok pusztulását és ezzel párhuzamosan a Candida spp., Pseudomonas-fajok, Acinetobacter-fajok, Clostridium difficile és antibiotikum-rezisztens - például: ESBL-termelő E. coli-törzsek - elszaporodását okozza. Ismert, hogy az antibiotikum-kezelés akár hosszú távon is megváltoztathatja a bélmikrobiomot. A bélmikrobiom tanulmányozására új metagenomikai technikák - például: 16S rRNS génkészletek vizsgálata és bioinformatikai eszközök - kerültek kifejlesztésre, hogy a mikroorganizmusok közösségének szerkezetét, múködését és a lehetséges összefüggéseket vizsgálják. Az előadás a különböző antibiotikumok rövid, illetve hosszú távú, bélflórára kifejtett hatását foglalja össze az újszülöttkortól az időskorig, ismertetve egyben a metagenomikai módszereket is.
\end{abstract}




\title{
Az obesitas hatása a gyógyszeres terápiára, táplálásterápiára és a farmakonutrícióra - Rövid áttekintés
}

\author{
Télessy István
}

\author{
Pécsi Tudományegyetem, Gyógyszerésztudományi Kar, Gyógyszerészeti Intézet, Pécs
}

\begin{abstract}
Obesitas kapcsán elsősorban az eloszlási térfogat megemelkedése miatt fellépő farmakokinetikai változások jutnak eszünkbe. Ez szinte minden gyógyszert érint, de - sajnos - eltérő mértékben. Így például a midazolam esetében $5 \mathrm{mg}$ iv. bolus beadását követő 60 . percben egy $76 \mathrm{~kg}$-os egyénben $30 \mathrm{ng} / \mathrm{ml}$, a körülbelül kétszeres tömegü (145 kg-os) betegben viszont csak $10 \mathrm{ng} / \mathrm{ml}$ vérszint mérhető. De - a hiedelmekkel ellentétben - ez nem minden hatóanyagra és gyógyszerkészítményre érvényes egyformán, például az orális antikoncipiensek esetében nem kell dózismódosításhoz folyamodnunk a biztonságos hatás fenntartásához. Obesitasban a gastrointestinalis rendszer is morfológiai változáson megy át, ezzel a gyógyszerek és tápanyagok felszívódása is változik. De az adipocyták által termelt hormonok is befolyásolják mind a gyógyszerek farmakodinámiás viselkedését, mind a táplálásterápiában érintett mikro- és makronutriensek felszívódását, metabolizmusát és ürülését. Egy táplálásterápia szempontjából releváns példa az intestinalis glükózfelvétel, amely egészségesekben inzulinnal dózisfüggő módon befolyásolható, obes egyénekben viszont - glykaemiás állapottól függetlenül - e tekintetben inzulinrezisztencia mutatható ki. Más irányú - egyelőre in vitro - kutatások arra világítottak rá, hogy egyes rákos elfajulások kezelése során az adipocyták védelmet nyújtanak a neoplazma sejtjeinek, s ezzel terápiarezisztenciát okoznak a terápiában alkalmazott gyógyszerekkel, például lymphoblastos leukaemia esetében a citosztatikumokkal (vincristin, daunorubicin) és szteroidokkal (például dexametazon) szemben. Ugyancsak számottevő befolyásoló tényező az obesitasban megváltozó mikrobióta, amely a beteg energia-homeosztázisát, valamint szénhidrát-anyagcseréjét is megváltoztatja. Erre kiváló példa - a normális súlyúakkal szemben obes betegek vastagbelében mérhető lényegesen magasabb SCFA-tartalom, azonos szubsztrátbevitel mellett. Ezeket és a hasonló változásokat, összefüggéseket a kutatás egyre gyakrabban tárja fel, s a modern ismereteket - amelyeknek részletes áttekintését adja a szerző előadásában - a táplálásterápiában és farmakonutrícióban részesített betegek kezelése során is figyelembe kell venni.
\end{abstract}

\section{A mikroflóra szerepe a szervezet öregedési folyamatában}

\section{Wacha Judit}

\author{
Semmelweis Egyetem, Általános Orvostudományi Kar, I. Sebészeti Klinika, Budapest
}

Az emberiség évezredes törekvése a hosszú, egészséges élet elérése. Célunk a biológiai és szellemi hanyatlás lelassítása, lehetőségeink a tápláltsági állapot és a szervezet homeosztázisának fenntartása, a toxikus károsodások kivédése, a krónikus betegségek megelőzése. 100 éve Mecsnyikov, Nobel-díjas tudós, az élet meghosszabbításának lehetőségét a laktobacillusok tevékenységében látta. Hol tart ma a tudomány a mikrobióta kutatásában, közelebb jutottunk-e Mecsnyikov optimista szemléletének igazolásához? Tudjuk, hogy a szervezetünkkel szimbiózisban élő baktériumok számos élettani funkciónkat befolyásolják. Modulálják az immunrendszert, szerepük van az akut és a krónikus betegségek alakulásában. A kor előrehaladtával párhuzamosan megváltozik a bélflóra összetétele, jellegzetes immunológiai változások következnek be. Fiatalkorban a Bacteroidetes és Firmicutes közötti egyensúly T-sejt-aktiválódáshoz vezet, magasabb az IL-10 és alacsonyabb az IL-17 szintje, míg időskorban a fokozott Th17-sejt-aktiváció a gyulladásos folyamatokat erősíti. Az öregedési folyamatban a genetika és a környezeti tényezők mellett a diszbiózis okozta krónikus alacsony szintű gyulladás (inflammaging) is fontos kóroki tényező, szerepe van a korral együtt járó komplikációk kialakulásában és progressziójában (csontritkulás, diabetes, cerebro- és cardiovascularis, neuropszichiátriai, degeneratív mozgásszervi és immunológiai megbetegedések, rák). A bélflóra fontos tényező az egészség megőrzésében. Jellemző eltérések mutathatók ki a bélflóra összetételében számos krónikus nem fertőző betegségben és anyagcserezavarban. Az utóbbi évek klinikai vizsgálatait áttekintve felmértük, hogy a bélflóraváltozásnak milyen klinikai relevanciái vannak és ez milyen terápiás következményeket von maga után. Speciális étrend-kiegészítók (pre- és a probiotikumok) minőségi és mennyiségi változásokat eredményeznek a bélflóra összetételében, megváltoztatják a bél barrierfunkcióját, az immunrendszer múködését, hatással vannak a krónikus gyulladásos folyamatokra, amelynek megelőzése a leghatásosabb módszere az öregedési folyamat megfékezésének. A probiotikumok által termelt luminális poliaminok a gyulladásos folyamat gátlásával szerepet játszhatnak az öregedés lelassításában és az élet meghosszabbításában. A kóros fermentatív folyamatok gátlásával csökkentik a toxikus anyagcseretermékek felszaporodását, új potenciális lehetőséget jelentenek számos betegség megelőzésében és kezelésében. 


\title{
Bejelentett előadások
}

\author{
A preventív táplálás jelentősége fej-nyaki daganatos betegek esetén \\ Andó Réka - Szabó Balázs - Molnárné László Gabriella - Tamás László
}

Semmelweis Egyetem, Általános Orvostudományi Kar, Fül-Orr-Gégészeti és Fej-Nyaksebészeti Klinika, Budapest

A szájüreg-, garat- és gégedaganatos betegek mindegyike a kórlefolyás, illetve a különböző onkológiai kezelések során, előbb vagy utóbb, átmenetileg vagy véglegesen nyelészavarral néz szembe. Az ooket ellátó szakemberek felelőssége, hogy megfontolt, gondos betegvezetéssel lehetőleg megakadályozzák a daganatos betegek alultápláltságának kialakulását. Ahogy oly sokszor látjuk a klinikai gyakorlatban, tumoros cachektizálódott, alultáplált betegek előrehaladott tumoros folyamattal jelentkeznek az orvosnál kifejezett nyelési panaszra hivatkozva. E betegek megfelelő táplálási állapotba hozása a szervezetet megerőltető sebészi, sugár- vagy kemoterápia előtt ugyancsak komoly kihívást jelent. Klinikánk fontos feladatul tűzte ki, hogy a táplálásterápia a daganatellenes terápiák elválaszthatatlan részét képezze. A tápláltsági szintfelmérés után, ha szükséges, kiegészítő táplálást kap a beteg. Amíg szájon át képes táplálékot fogyasztani, addig az iható tápszer biztosíthatja az állapotának megfelelő energiabevitelt. Mứtétek után átmenetileg nasogastricus szondán át tápláljuk a betegeket. Ha hosszabb gyógyulási időre kell számítani, mint 3 hét, akkor előnyösebb a PEG-szonda alkalmazása. Klinikánkon egyre több beteg esetén történik preventíven PEG-beültetés. A preventíven végzett beavatkozásokkal jelentősen csökkenthetőek a PEG okozta szövődmények is. Az alábbi esetekben javasolt betegeinknek a tehermentesítő PEG-mütét: 1. Részleges gégeeltávolítás és/vagy nagy nyaki mútét esetén, mert ezek a betegek nehezen tanulnak meg újra nyelni, gyakoribbak a szövődmények, felépülésük hosszú időt vesz igénybe. 2. Dysphagiás betegek kemoterápiája esetén, mert a citosztatikumok okozta mellékhatások önmagukban is rontják az általános állapotot. 3. Sugárkezelés során égés, fájdalom miatt hosszú ideig nem tudnak a betegek kielégítően táplálkozni, sokszor még a folyadékbevitel is akadályozott. Intézetünkben ezeket az elveket alapul véve történik a betegek táplálkozástani gondozása. A táplálkozási tervet minden beteg esetén személyre szabottan állítjuk fel. Amennyiben sebészi terápiára számítunk, előtérbe helyezzük a sebgyógyulást pozitívan befolyásoló készítményeket. Az utóbbi 3 év beteganyagát feldolgozva látható, hogy rohamosan nő a PEG-beültetések száma (2012-ben 12, 2013-ban 22, 2014-ben 34). E betegek túlnyomó része (85\%-a) onkológiai beteg, akiknek 25\%-ánál történt preventív PEG-beültetés a tanulmányozott időszakban. A fent részletezett szemlélet figyelembevételével csak az utolsó évre vonatkoztatva ez az arány $35 \%$.

\section{A dietetikus szerepe a béldaganatos betegek táplálásterápiájában - Esetismertetés Baloghné Farkas Krisztina ${ }^{1}$ - Kádas Júlia ${ }^{2}$ - Máté Miklós $^{3}$ Brenner Barnabás ${ }^{3}$ - Fejér Csaba ${ }^{4}$ - Straub Éva ${ }^{4}$}

Szent Imre Egyetemi Oktatókórház, ${ }^{1}$ Dietetikai Szolgálat, ${ }^{2}$ Onkológiai Osztály, ${ }^{3}$ Sebészet, ${ }^{4}$ Aneszteziológiai és Intenzív Terápiás Osztály, Budapest

Daganatos betegségek kezelésénél fontos a gyors diagnózis felállítása, a megfelelő sebészi intervenció és onkoterápia alkalmazása, illetve a tápláltsági állapothoz alkalmazkodó dietoterápia kialakítása. 38 éves nőbetegünknél ez év márciusában diagnosztizálták coecum- és rectumdaganatát. Áprilisban onkológiai bizottság mútétet, majd onkológiai kezelést javasolt. Cachexiás állapot miatt kérték a segítségünket. A beteg tápláltsági állapotára utaló paraméterek és laborleletek: BMI: 14,5 kg/m², öf: 55,4 g/l, alb.: 35,5 g/l, Hgb: 77,6 g/l, se-vas: 0,9 بmol/1. Fehérjehiányos malnutritiót és vashiányos anaemiát igazoltak. A rosszindulatú, folyamatos anémizálódást mutató daganat miatt a műtétig a táplálásterápia kialakítására és roborálásra négy hét állt rendelkezésünkre. Első lépésként a táplálkozási napló segítségével felmértük a fogyasztott étrend átlagos napi tápanyagtartalmát: EN: 1600 kcal, fehérje: 10e\%, zsír: 50e\%, szénhidrát: $40 \mathrm{e} \%$ volt, amely nem fedezte a napi szükségletet. Dietetikai konzílium után a beteg étkezése átlagosan $1800 \mathrm{kcal} \mathrm{EN}, 17 \mathrm{e} \%$ fehérje-, $51 \mathrm{e} \%$ zsír-, 32e\% szénhidrátbevitelre módosult. A hatékony roborálás elérése céljából kiegészítő mesterséges enteralis táplálásra volt szükség. A mútétig 3 kg-ot hízott. Május közepén jobb oldali hemicolectomia és abdominoperinealis rectumexstirpatio történt. Posztoperatív időszakban glutaminnal kiegészített parenteralis táplálásban részesült, majd enteralis táplálását újra felépítettük. A mútétet követő 9. napon távozott otthonába szövődménymentesen. A beteg jó compliance-e, valamint a hatékony, körültekintő orvosi és dietetikusi csapatmunka eredményeképpen betegünk a perioperatív időszakban sem fogyott. Négy héttel a mútét után a páciens BMI-je: 17,5 $\mathrm{kg} / \mathrm{m}^{2}$, napi átlagos EN-bevitele 2-3000 kcal, fehérje: 14e\%, zsír: $51 \mathrm{e} \%$, szénhidrát: 45e\%, amely jó eredmény, de további orvosi/dietetikai monitorozás szükséges a kezdődő kemoterápia miatt. A fiatal, kétgyermekes családanya esete jól prezentálja a gyors és megfelelő szakmai tudású reakciót és a teammunka fontosságát. Ezek az eredmények csak múködő kórházi táplálási team mellett valósulhatnak meg. 


\title{
Magisztrális és gyári teljes parenteralis táplálóoldatok a gyermekgyógyászatban \\ Cseh Áron - Müller Katalin Eszter - Arató András - Veres Gábor Turmezeiné Horváth Judit - Szabó Attila - Máttyus István
}

\author{
Semmelweis Egyetem, Általános Orvostudumányi Kar, I. Gyermekgyógyászati Klinika, Budapest
}

\begin{abstract}
A gyermekkori bélműtéteket követően egyre gyakrabban tartósan alkalmazunk parenteralis táplálást. Ennek módja lehet gyári vagy magisztrális előre elkészített all-in-one és helyben kevert oldat adása is. Az előre összeállított all-inone tápoldatok esetén az oldatok költsége, hibalehetősége és a fertőzés kockázata alacsonyabb, ugyanakkor a helyben kevert infúziók gyorsan változtathatóak a gyermekek aktuális állapotához. Célul túztük ki, hogy krónikusan parenteralis táplálást kapó gyermekek esetében leírjuk az előre összeállított és helyben kevert infúziós oldatok használatának aspektusait. Az utóbbi 3 évben klinikánkon kezelt gyermekek esetében vizsgáltuk a szövődmények kialakulásának gyakoriságát parenteralis táplálásban. A vizsgált időszakban, 2012. január 1-jétől 2015. július 1-jéig, kezdetben kórházi, majd otthoni parenteralis táplálásban is részesültek gyermekek. 37 esetben alkalmaztunk tartós parenteralis táplálást gyári vagy magisztrális oldattal, minimum 2 hét és 3,5 év közötti időtartamban. Ezen oldatok esetében mindösszesen 2 alkalommal észleltünk súlyos szeptikus szövődményt infúzióval összefüggésben. A krónikus parenteralis táplálásra szoruló gyermekek esetében a felnőttekéhez hasonló biztonsággal alkalmazhatók az előre elkészített táplálóoldatok. Több gyermek kezelése esetén nemcsak költségeket lehet ezúton megtakarítani, hanem a szövődmények kockázata is csökkenthető.
\end{abstract}

\section{Gyulladásos bélbetegek táplálkozási szokásainak és testösszetételének változása a biológiai kezelés ideje alatt}

\author{
Dakó Sarolta $^{1}$ - Molnár Andrea ${ }^{2}$ - Csontos Ágnes Anna ${ }^{3}$ - Pálfi Erzsébet ${ }^{1}$
} Piri Zsolt Mátyás ${ }^{3}$ - Katona Balázs ${ }^{3}$ - Miheller Pál ${ }^{3}$

\author{
${ }^{1}$ Semmelweis Egyetem, Egészségtudományi Kar, Dietetikai és Táplálkozástudományi Tanszék, Budapest \\ ${ }^{2}$ Semmelweis Egyetem Doktori Iskola, Budapest \\ ${ }^{3}$ Semmelweis Egyetem, Általános Orvostudományi Kar, II. Belgyógyászati Klinika, Budapest
}

A gyulladásos bélbetegségek kezelésében a táplálkozás és táplálásterápia szerepe bizonyított. A biológiai kezelés megjelenésével új kérdések merülnek fel a dietoterápia vonatkozásában is. A vizsgálat célja a biológiai kezelésben részesülő gyulladásos bélbetegek táplálkozási szokásainak, testösszetételének vizsgálata, valamint a kezelés hatására bekövetkezett változások és a táplálkozás közötti összefüggések feltárása volt. A vizsgálat alanyai a Semmelweis Egyetem II. Belgyógyászati Klinikáján biológiai terápiában részesülő gyulladásos bélbetegek ( 35 fó, $33 \pm 12$ év) voltak, akik infliximab- és adalimumabkezelést kaptak. A vizsgálat során összehasonlítottuk a biológiai kezelés előtti és kezelés alatti táplálkozásukat élelmiszer-fogyasztási gyakorisági kérdőív (sqFFQ) és 3 napos táplálkozási napló segítségével, amelyet interjúval validáltunk. Az étrendek energia- és tápanyagtartalmának számolása NutriComp DietCad programmal történt. A betegek testösszetételét InBody 720-as készülékkel mértük a kezelés megkezdésekor és a kontrollok alkalmával. Az adatokat kétmintás t-próbával, páros t-teszttel és ANOVA-analízissel értékeltük (Microsoft Excel 2007, SPSS 20.0). A biológiai kezelés során a betegek testtömege, ezen belül a zsírmentes testtömeg és vázizomtömeg jelentős növekedést mutatott (FFMI 2\%-kal, SMI 3\%-kal nőtt). Ennek hátterében a szignifikánsan magasabb energia$(+36 \%)$ és fehérjebevitel $(+39 \%)$ állhat. Az energiabevitel testtömegre vonatkoztatva is emelkedett, a kezelés alatt már elérte a szükségletnek megfelelő szintet $(28,5 \pm 9,57 \mathrm{kcal})$. Szignifikáns eltérést tapasztaltunk a kezelés előtti és utáni zsírbevitel között (47\%-kal nőtt), a telített, egyszeresen és többszörösen telítetlen zsírsavak szintje is szignifikánsan emelkedett. A szénhidrátbevitelben csak kisebb eltérés volt látható (28\%-kal nőtt), amelyet elsősorban az emelkedett krisztalloid szénhidrát fogyasztása okozott. Az élelmiszerek közül emelkedett a tej és egyes tejtermékek, húsfélék és felvágottak, zöldségek és gyümölcsök, valamint az édességek fogyasztása. A kapott eredmények arra engednek következtetni, hogy a biológiai kezelés hatására a szervezetben bekövetkezett pozitív változások (gyulladás csökkenése, kevesebb panasz) szabadabb táplálkozást tesznek lehetôvé a betegek számára. Az emelkedett fehérjebevitel mellett az izomtömeg növekedése különösen fontos ennél a sarcopenia szempontjából fokozottan veszélyeztetett betegcsoportnál. 


\section{Táplálásterápia hatékonyságának értékelése a testösszetétel vizsgálatával onkohematológiai betegségben szenvedő gyermekekben

\author{
Dóka Júlia - Czuppon Krisztina - Tomsits Erika
}

Semmelweis Egyetem, Általános Orvostudományi Kar, II. Gyermekgyógyászati Klinika, Budapest

Tumoros betegekben a megfelelő tápláltsági állapot csökkenti a citosztatikus kezelések szeptikus szövődményeinek, a kezelések halasztási kényszereinek gyakoriságát, javítja a betegséggel való megküzdés esélyét. Táplálási terápiával megelőzhető, illetve kialakulás esetén kedvezően befolyásolható a betegek kóros tápláltsági állapota. Onkohematológiai betegségben szenvedő gyermekekben a táplálásterápia eredményességét vizsgáltuk a testösszetétel meghatározásával, bioimpedancia- (BIA-) méréssel (InBody 720). 2013 júliusától 42 gyermeknél történt BIA a táplálásterápia megkezdése előtt és azt követően 3,4 (2-8) alkalommal. Összesen 144 mérés eredményét értékeltük. A táplálásterápia 10 gyermek esetében szondatáplálás (NG, illetve PEG, PEJ) volt, tápszerrel történő kizárólagos táplálást a szondatápláltak kaptak a táplálásterápia egy-egy időszakában. A táplálásterápia kezdetén 25 beteg BMI-percentilje a normáltartományban volt, három beteg obes, 14 beteg BMI-percentil szerint alultáplált volt. A táplálásterápia során 17 esetben csökkent a BMI, 5 esetben változatlan maradt. A táplálásterápia során a 20 emelkedő BMI-jű gyermeknél a BMI emelkedése ellenére 9 esetben a test zsírmentes tömege (fat free mass - FFM) csökkent. Az alultápláltak közül két esetben emelkedett a BMI-percentil a normális tartományba. 8 gyermek esetében $(8 / 42)$ azonban annak ellenére emelkedett a test fehérjetartalma, hogy a táplálásterápia mellett a BMI nem változott vagy csökkent. A táplálásterápia eredményességének megítélésében nem megbízható módszer a betegek testtömeg-, BMI- vagy BMI-percentilváltozásának nyomon követése. BIA segítségével mellékhatások nélkül, több szempontot is figyelembe véve, lehetséges a legmegfelelőbb táplálásterápia alkalmazása. A testösszetétel változásának gyors és érzékeny nyomon követése a gyermek és a szülő számára ösztönző a megfelelő táplálásterápiában való együttmúködésre. Az optimális testösszetétel eléréséhez a táplálásterápián kívül fontos a beteg mozgásszegénysége miatt kialakuló izomleépülés elkerülése is.

\section{A klinikai táplálásterápia útja a kezdeményezéstől az intézeti szabályzatig Ferdinandy Csilla}

Péterfy Sándor Utcai Kórház-Rendelőintézet és Baleseti Központ, Budapest

Számtalan tudományos fórumon taglaltuk már a klinikai táplálásterápia fontosságát, patofiziológiai magyarázatát, betegjólléti és gazdasági jelentőségét, azonban a gyakorlati megvalósítás vonatkozásában hazánkban - a néhány példamutató intézmény munkásságától eltekintve - a téma még mindig elszomorítóan kevés hangsúlyt kap. Jelen prezentáció fókuszában elsősorban azon technikai, tudományos és módszertani lépések bemutatása áll, amellyel hazai körülmények között, reális és megtérülő anyagi ráfordítással, néhány ember lelkesedésétől vezérelve egy táplálási munkacsoport felépíthető, múködtethető és kézzelfogható, valid eredményeket produkál. Első lépésként obszervációs keresztmetszeti vizsgálat keretében demográfiai és tápláltsági adatokat gyüjtöttünk csípőtáji törés (monotrauma) miatt felvett, tiszta tudatú betegek körében, beleegyezésükkel a felvételüket követô napokban. Az adatgyújtéshez az Európai Táplálási Társaság (ESPEN) Nutrition Risk Screening (NRS-ESPEN, Guideline for Nutrition Screening, 2002) kérdőívét alkalmaztuk a baleseti központra adaptált formában, ami alapján táplálásterápiára szorulónak minősülő, avagy 3-as rizikópont felett álló betegek részére személyre szabott táplálásterápiát indítottunk, majd az utánkövetés adatait kiértékeltük. A vizsgálatba 125 fő (96 nő és 29 férfi) került bevonásra, átlagéletkoruk 70,6 év volt. Az NRS adatai és a rizikópontok kiszámolása alapján a felmért populáció több mint $76 \%$-a igényelte a klinikai táplálásterápia elindítását, ezen betegek körülbelül 50\%-ának rizikópontja 6, míg 45\%-a 5, 5\%-a pedig 4 rizikóponttal rendelkezett. További 14\%-uk tápláltsági állapota folyamatos megfigyelést igényelt, 10\%-uk pedig nem szorult táplálékkiegészítésre. A vizsgált populációban a leggyakoribb rizikófaktorok az életkor, az alacsony BMI, valamint az elégséges táplálékfelvétel hiánya voltak. 


\title{
Daganatos betegek tápláltsági állapotának és táplálkozási nehézségeinek felmérése - dietetikusi intervenciók
}

\author{
Galló Nóra ${ }^{1}$ - Varga Mária ${ }^{2}$ - Tátrai-Németh Katalin ${ }^{1}$ - Pálfi Erzsébet ${ }^{1}$ \\ 'Semmelweis Egyetem, Egészségtudományi Kar, Alkalmazott Egészségtudományi Intézet, \\ Dietetikai és Táplálkozástudományi Tanszék, Budapest \\ ${ }^{2}$ Szent Imre Egyetemi Oktatókórház, Dietetikai Szolgálat, Budapest
}

\begin{abstract}
Daganatos betegségekben a tumor és a kezelések hatást gyakorolnak az anyagcserére, táplálkozásra, így a tápláltsági állapotra. Cél: A malnutritióhoz és sarcopeniához vezetố táplálkozási nehézségek és a dietetikusi intervenció lehetőségeinek feltárása volt az angol, illetve amerikai NCP-modellek alapján. Bizonyítani kívántuk, hogy a táplálkozási szokások mennyiség és minőség tekintetében is megváltoznak, továbbá, hogy a betegek energia- és tápanyagbevitele nem megfelelő. Kérdésként fogalmaztuk meg, hogy mely betegek kapnak klinikai táplálást. Betegek: A kutatásba a fekvőbeteg- $(64,33 \pm 18,62$ év, 22 férfi/23 nő) és járóbeteg- $(63,38 \pm 16,08$ év, 9 férfi/15 nő) ellátásból választottuk ki az alanyokat, hiszen a daganatos betegek mindkét ellátási területen megjelennek, illetve eltérő dietetikusi feladattal kell számolnunk. Módszerek: Malnutritiorizikó-szürést végeztünk NRS 2002 módszerrel. A tápláltsági állapotot mért antropometriai paraméterekkel és testösszetétel-analízissel (4 pontos BIA) állapítottuk meg. A táplálkozás változását validált táplálkozási naplóval és 24 órás visszakérdezéssel mértük. Az energia- és tápanyagbevitelt NutriComp szoftver segítségével elemeztük. Eredmények: A fekvő betegek 100\%-a veszélyeztetett malnutritióra (60\% közepes, 12\% sú-

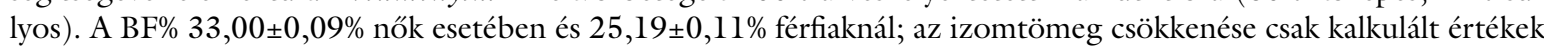
alapján valószínúsíthető. A betegek $45 \%$-a a korábban elfogyasztott adag 0-50\%-át tudja megenni. A járó betegek 16\%-a veszélyeztetett enyhe malnutritióra, és csak 8\%-uk étvágytalan. A járó betegek $72 \%$-a túlsúlyos-elhízott, azon-

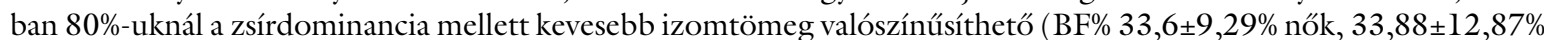
férfiak; SM\% 31,71 $\pm 8,16 \%$ ). A fekvő betegek még a kiegészítő táplálással is csak 1800 kcal-t fogyasztanak el. $22 \%$ részesül tápszeres kiegészítésben, de a javasolt mennyiség 50-75\%-a fogy el ténylegesen. 41\% súlyos rizikójú beteg egyáltalán nem kap ONS-t. Következtetések: A daganatos betegek tápláltsági állapotát komplex módon kell vizsgálni. Időben el kell kezdeni a tápszeres kiegészítést, szonda- vagy akár parenteralis táplálást.
\end{abstract}

\section{Az időskorúak táplálása: a tápszeres ellátás gyakorlata a szociális és fekvőbeteg-ellátó intézményekben}

\author{
Kovács Ágota ${ }^{1,2,3}$ - Zelkó Romána ${ }^{4}$ - Kovácsné Balogh Judit ${ }^{4,5}$ \\ 'Országos Gyógyszerészeti és Élelmezés-egészségügyi Intézet, Budapest \\ ${ }^{2}$ Semmelweis Egyetem, Gyógyszerésztudományi Kar, Budapest \\ ${ }^{3}$ Semmelweis Egyetem, Egészségügyi Menedzserképző Központ, Budapest \\ ${ }^{4}$ Semmelweis Egyetem, Gyógyszerésztudományi Kar, \\ Egyetemi Gyógyszertár - Gyógyszerügyi Szervezési Intézet, Budapest \\ ${ }^{5}$ Semmelweis Egyetem, Egészségtudományi Kar, Egészségtudományi Klinikai Tanszék, Budapest
}

\begin{abstract}
Magyarországon a 60 év feletti időskorúak közül több mint 70 ezren élnek tartós bentlakásos intézményekben. Számos vizsgálatot végeztek azzal kapcsolatban, hogy miként történik a tápláltsági állapot felmérése és a mesterséges táplálás biztosítása a fekvőbeteg-ellátó intézményekben, azonban az még kevésbé ismert, hogy mindez hogyan müködik az idősek ellátását huzamosabb ideig ellátó szociális intézményekben, azaz idősotthonokban. Vizsgálataink során budapesti és vidéki idősotthonokba, illetve kórházi krónikus osztályokra látogattunk el. Adatokat 47 szociális otthonban élő és 20 krónikus osztályon kezelt beteg gyógyszerelési és gondozási dokumentációiból gyüjtöttünk, akik iható tápszeres ellátásban vagy szondatáplálásban részesültek, emellett kérdőíves felmérést végeztünk a nővérek és a dietetikusok körében is. Ezek alapján összehasonlítottuk a mesterséges táplálás gyakorlatát a fekvőbeteg-ellátó és a szociális intézményekben. A hiányosságok feltárása mellett megpróbáltuk megtalálni azokat a lehetőségeket, amelyekkel az ellátás színvonala javítható. Az eredmények összegzéseként megállapíthatjuk, hogy a tápláltsági állapot felmérése nélkülözhetetlen mind a szociális, mind az egészségügyi intézményekben. Az időskori gyengeség, étvágytalanság gyakran demenciával párosulva szükségessé teszi a tápszeres kiegészítést, tumor, szkizofrénia és anorexia esetén pedig a súlyos fázis időszakában javasolt a tápszerek alkalmazása. Enteralis táplálás során egyedül hasmenés lépett fel mellékhatásként, amely azonban elkerülhető, ha odafigyelnek a tápszer megfelelő összetételére és alkalmazására. A betegek állapotát leginkább nyomon követő nővérek számára megfelelő oktatást kellene biztosítani a mesterséges táplálásról. A rendszeres testtömeg- és testmagasságmérésre, valamint BMI-számolásra nagyobb hangsúlyt kellene fektetni, azonban ehhez gyakran nem állnak rendelkezésre a szükséges feltételek. A tápszeres ellátást sok esetben finanszírozási problémák is nehezítik. A szociális intézményekben dietetikus alkalmazása javasolt lenne a be-
\end{abstract}


tegek személyre szabott és szakszerü étrendjének kialakításához. Az eredmények alapján a fekvőbeteg-intézmények magasabb színvonalú ellátást nyújtanak mesterséges táplálás szempontjából, mint a szociális intézmények, ezért e terület fejlesztésére nagyobb hangsúlyt kellene fektetni.

\title{
A gyermekkori tartós parenteralis táplálás sikerei és nehézségei

\author{
Máttyus István - Túrmezei Judit - Kálmán Attila - Arató András
}

Semmelweis Egyetem, Általános Orvostudományi Kar, I. Gyermekgyógyászati Klinika, Budapest

Súlyos bélmúködési zavar esetén az enteralis táplálékfelvétel megfelelően összeállított komplex infúziós oldatok segítségével helyettesíthető. Az 1998-tól 2015-ig terjedő időszakban 45 beteget kezeltünk 3 hónapnál hosszabb ideig tartós, teljes értékű infúzióval, az ő adataikat dolgoztuk fel előadásunkban. A terápia kezdetén mindegyik gyermek csecsemőkorú volt. Az egyre jobb minőségű oldatok segítségével olyan betegeket is életben tudtunk tartani, akik korábban meghaltak. A fenti időszak alatt 8 beteget vesztettünk el, a halálokok között a májelégtelenség mellett megjelent a szepszis is. A fennmaradó 37-ből mindössze 4 részesül napjainkban is teljes értékú infúzióban. Nemrég állítottuk le egy több mint 3 éven át rövidbél-szindróma miatt otthon infundált gyermek kezelését. A sikerek mellett tartós problémákra is megoldást kell keresnünk: az egyedi oldatokat továbbra is csak két gyógyszertár képes Magyarországon összeállítani. A tasakok mérete és költsége túl nagy. A fertőzések, centráliskanül-kolonizáció megelőzésére célszerú lenne bevezetni és egységesen alkalmazni a 70\%-os alkohol helyett a korszerúbb, de drágább Taurolisint. Az OEP által megkívánt adminisztráció meglehetősen bonyolult. Kisgyermekek számára szükséges egyedi oldatok esetén az állami finanszírozás nem mindig fedezi a költségeket. A teljes parenteralis táplálás jól alkalmazható módszer a gyermekkori bélelégtelenség kezelésében, túlélését jelentős mértékben javítja. Az említett nehézségek megoldásával még több beteget segíthetnénk a gyógyuláshoz.

\section{STRONG malnutritiorizikó és a percentilisek közötti összefüggések. STRONG 2.0}

\author{
Müller Katalin - Cseh Áron - STRONG Study Group - Veres Gábor
}

Semmelweis Egyetem, Általános Orvostudományi Kar, I. Gyermekgyógyászati Klinika, Budapest

A STRONG a malnutritio rizikóját szűrő pontrendszer, ezt alkalmazva mértük fel korábbi vizsgálatunkban hazánkban a malnutritio rizikóját. Az ambuláns gyermekek 65\%-ában állt fenn rizikó, 15\%-ukban a kockázat magasnak bizonyult. Jelen tanulmányunkban a malnutritióra utaló percentilisértékek és a STRONG által mutatott rizikó közötti összefüggéseket elemeztük. A STRONG 2.0 felmérésben 28 intézmény vett részt. A központok profiljai eltérőek voltak: gyermekgasztroenterológiai, -onkológiai, -neurológiai, -nefrológiai és általános gyermekgyógyászati intézményekben gyüjtöttük az adatokat. A STRONG-szúrést összesen 1117 gyermeknél végeztük el. A szűrőlap mellett a gyermekek korát, nemét, valamint testsúly-, testmagasságértékeit is rögzítettük. A vizsgálatba bevont 1117 gyermek közül 1089-nél állt rendelkezésre minden adat (átlagéletkor 6,7 év [0-16 év], 530 fiú, 559 lány]). Közülük mintegy 64\%-nál állt fenn a malnutritio rizikója (701/1089), 12\%-nál a kockázat magas volt (133/1089). A STRONG-pontok átlaga nem különbözött a két nemben $(1,5$ vs. 1,6, p =0,562). A malnutritiorizikó gyakorisága a különböző korcsoportokban nem különbözött. A STRONG-pontszám mind a testsúlypercentilis- $(\mathrm{p}<0,0001)$, mind a testmagasság-percentilis- $(\mathrm{p}<0,0001)$ értékekkel szignifikáns negatív korrelációt mutatott. Azon betegek közül, akiknek a testtömeg- és testmagasság-percentilise is 5 alatt volt, 85\%-ban állt fenn a malnutritio rizikója, és 15\%-uknál (17/114) a STRONG nem mutatta a malnutritio kockázatának fennállását. Az eredményeket összefoglalva: vizsgálatunkban a malnutritio rizikóját a korábbi felméréssel megegyezőnek találtuk a hazai egészségügyi intézményekben. A percentilisértékek és a STRONG-rizikó között igazolt korreláció azt mutatja, hogy a STRONG-kérdőív hasznos lehet a betegek tápláltsági állapotának szürésére. Előnye a percentilisekkel szemben, hogy nem igényel mérést, követést, könynyen és azonnal elvégezhető, különösebb speciális ismeretek nélkül. 


\title{
Gastrointestinalis tumoros betegek tápláltsági állapotának felmérése osztályunkon
}

\author{
Révész Erzsébet - Altorjay Áron
}

\author{
Szent György Egyetemi Oktató Kórház, Székesfehérvár
}

\begin{abstract}
A daganatos betegek tápláltsági állapotának felmérése és a perioperatív táplálásuk fontos feladat, mivel optimális tápláltsági állapotuk nagyban hozzájárul a mütét sikeréhez, a posztoperatív szövődmények minimalizálásához. A gastrointestinalis tumorok előfordulásának megoszlása eltolódást mutat a fiatalabb korosztály felé. 2014 szeptemberében osztályunkon megkezdtük a gastrointestinalis tumoros betegek tápláltsági állapotának felmérését. MUST és NRS 2002 szürőrendszert használtunk, emellett laborvizsgálatokat végeztünk. 9 hónap alatt 234 utánkövetés történt. Betegeink 80,6\%-a 51 és 80 év közötti, $11,2 \%$-uk 80 év feletti, míg 8,1\%-uk 50 év alatti volt. A betegek közel $85 \%$-a 20 feletti BMI-vel rendelkezett, és 55\%-uk a túlsúlyos vagy már a kórosan elhízott csoportba tartozott. MUST-szürésükről elmondható, hogy míg 50,8\%-uk az alacsony kockázati csoportba sorolandó, addig NRS 2002-szưrésük már nagyobb szórást mutatott. Tumormegoszlás tekintetében a betegeink 76,5\%-a colorectalis tumoros volt, ezen belül Dukes B1 9,8\%, Dukes B2 24,6\%, Dukes C1 5,6\%, Dukes C2 27,9\% és Dukes D 32,1\%. A többi 10,3\%-ban gyomor-, 0,81\%-ban nyelöcső- és 6,40\%-ban pancreastumor, míg 5,98\%-ban a végleges szövettan benignus sejtképet mutatott. Laboreltéréseikről elmondható, hogy 73,5\%-uk már anaemiás volt a mútét előtt, lymphocytaarányuk 76,1\%-uknál alacsony volt, ezzel szemben csupán a betegek 36,7\%-ánál volt megfigyelhető alacsony összfehérje- és albuminszint, illetve 68,4\%-uknál emelkedett a CRP-szint, illetve gyorsult a We. Súlyveszteség a mütét előtt az esetek $50 \%$-ában volt, átlagosan $9,8 \mathrm{~kg}$. A mútét utáni időszakban ez átlagosan 4,1 kg volt a betegek $30 \%$-ánál. Sebészeti szövődmény 5,1\%-ban fordult elő. A vizsgált időszak alatt 14 beteget veszítettünk el. A gastrointestinalis tumoros betegségek, ezen belül colorectalis tumorok egyre fiatalabb korban és egyre kevesebb panasszal kerülnek felismerésre, sarcopeniájuk nehezen kimutatható. A gondos betegápolás, az aprólékos sebészi technika és a tápláltsági állapotra való odafigyelés nagyban segít, hogy kevesebb sebészeti szövődménnyel találkozzunk.
\end{abstract}

\section{Akut pancreatitises betegek táplálásterápiája osztályunkon \\ Szabó Anita ${ }^{1}$ - Horváth Miklós ${ }^{1}$ - Molnár Péter ${ }^{1}$ - Rácz Sándor ${ }^{1}$ - Ujhelyi Piroska ${ }^{1}$ Héra László ${ }^{1}$ - Futó Judit ${ }^{2}$ - Koncz Zsuzsa ${ }^{2}$ - Sahin Péter ${ }^{1}$}

\author{
${ }^{1}$ Dél-pesti Jahn Ferenc Kórház, Budapest \\ ${ }^{2}$ Szent Imre Egyetemi Oktatókórház, Budapest
}

\begin{abstract}
A következő kérdésekre kívántunk választ kapni: Megfelelő-e az akut pancreatitises betegek táplálásterápiája osztályunkon? A megfelelő táplálásterápiához szükséges-e az enteralis pumpa használata? Két hónap alatt osztályunkon akut pancreatitisszel osztályos protokoll szerint kezelt 24 beteg adatait dolgoztuk fel retrospektív módszerrel. Huszonnégy betegból 7 beteg nem felelt meg a beválasztási kritériumoknak. T-próba-módszerrel számoltunk szignifikanciát. Energiaszükségletet, figyelembe véve az akut állapotot, úgy számoltunk, hogy a beteg testsúlyát 18 kcal-val megszoroztuk, és $100 \mathrm{~kg}$ fölött maximalizáltuk az energiabevitelt 1800 kcal-ban. A következő adatokat vizsgáltuk: betegek életkora, neme, Ranson-score, felvételi és elbocsátáskor mért testsúly, felépített enteralis táplálás során beadott tápanyag energiatartama, a bevitt tápanyag százalékban megadott értéke a szükséglethez viszonyítva, enteralis táplálás módszere, kórházi kezelési napok száma. N: 17 (11 férfi, 6 nő), átlagéletkor: 58,2 év. Átlagos testtömegvesztés: $3,4 \mathrm{~kg},<5 \%$. Gravitációs módszerrel tápláltak (n: 7): átlagéletkor: 67,7 év; Ranson-score átlaga: 1 ; testtömegvesztés: $1,83 \mathrm{~kg}$; a bevitt tápanyag a szükséglethez viszonyítva: $88,16 \%$; kórházi kezelési napok száma: 9 . Enteralis pumpával tápláltak (n: 11): átlagéletkor: 53,1 év; Ranson-score: 1,64; testtömegvesztés: $4,18 \mathrm{~kg}$; a bevitt tápanyag a szükséglethez viszonyítva: 94,54\%; kórházi kezelési napok száma: 12,36. A gravitációs módszerrel tápláltak idősebbek (p: 0,075), és a Ranson-score szignifkánsan alacsonyabb (p: 0,045) volt. Tehát azok az idősebb, kisebb súlyú, jobb állapotú betegek, akik gravitációs eszközzel kapták a tápszert, összehasonlítva azokkal, akik enteralis pumpával kapták a tápszert, a szükségletük tükrében minimálisan, de kevesebb kalóriát kaptak $(88,16 \%$ vs. 94,54\%). Egyben nem szignifikánsan (9 vs. 12,36 nap, p: 0,15), de rövidebb ápolási időt töltöttek a kórházban. A fogyás mindkét csoportban a kórházi tartózkodás alatt $<5 \%(3,9 \%)$ volt, ami az irodalom alapján is igen jó eredmény. Mindezek alapján osztályunkon megfelelő az akut pancreatitis táplálásterápiája. Kevés enteralis pumpa áll rendelkezésre, ezért a fiatalabb és súlyosabb betegeket kezeltük enteralis pumpával, ami a megfeleló kalóriabevitelhez segítséget adott.
\end{abstract}




\title{
Átállás magisztrális all-in-one tápoldatról gyári all-in-one tápoldatra - 2015 Turmezeiné Horváth Judit — Tóth-Heyn Péter — Derzbach László
}

\author{
Semmelweis Egyetem, Általános Orvostudományi Kar, I. Gyermekgyógyászati Klinika, Budapest
}

Klinikánkon több, hosszú távú otthoni parenteralis táplálásban (OPT) részesülő gyermeket gondozunk. Bélműtétek következtében ők szinte születésüktől fogva magisztrális all-in-one tápoldatot kapnak. Nagyobb gyermekeink az alacsonyabb költségű gyári all-in-one tápoldatokat kapják, amelyeket a vízben és zsírban oldódó vitamin- és nyomelem-adalékanyagokkal ki kell egészíteni. Célul túztük ki, hogy a 3-4 év feletti, állandó magisztrális all-in-one tápoldattal táplált gyermekek esetében áttérjünk a gyári all-in-one parenteralis táplálásra. Egy 4 éves gyermekünk tápoldatösszetételét vetettük össze a gyári készítmények összetételeivel. Kiszámoltuk, figyelembe véve a beteg egyedi igényeit, mit kell pótolnunk a vitaminokon és a nyomelemeken kívül. A laboratóriumi paraméterek gyakori ellenőrzése mellett elkezdtük az átállást. Legfontosabb vizsgálatoknak a karbamid-nitrogén $(\mathrm{CN})$, triglicerid (TG), májenzimek (GOT, GPT) és koleszterin (leginkább a normáltartományon kívül eső paraméterek) méréseit találtuk, amit táblázatban foglaltunk össze. Bemutatjuk a gyermek súlygörbéjét is. Összegezve a normáltartományon kívül eső laboratóriumi mérések eredményeit, azt találtuk, hogy a magisztrális és gyári all-in-one tápoldatok mennyiségi különbségei pótolhatóak, illetve úgy ítéltük meg, hogy a szervezet alkalmazkodik a magasabb fehérjét tartalmazó új tápoldathoz. A régóta használt magisztrális tápoldat összetételének változtatása helyett a gyári készítmény alkalmazásával is szép súlygyarapodás érhető el. Megállapítottuk, hogy 4 év felett, a hosszú parenteralis táplálásra szoruló gyermekek ellátásához biztonságos, költséghatékony a gyári all-in-one tápoldatok alkalmazása. Az adalékanyagokkal való kiegészítésüket körültekintően, a sterilitás, kompatibilitási ajánlásoknak megfelelően kell végezni.

\section{Kanülmegtartási protokoll otthoni parenteralis táplálásban részesülő betegek körében}

\author{
Udvarhelyi Gábor $^{1}$ - Bíró Ilona ${ }^{1}$ - Mészárosné T. Andrea ${ }^{2}$ - Straub Éva ${ }^{2}$ - Fejér Csaba \\ Futó Judit ${ }^{2}$ - Topa Lajos ${ }^{1}$ - Sahin Péter ${ }^{3}$
}

Szent Imre Egyetemi Oktatókórház, ${ }^{1}$ Gasztroenterológia, ${ }^{2}$ Aneszteziológiai és Intenzív Terápiás Osztály, Budapest ${ }^{3}$ Dél-pesti Jahn Ferenc Kórház, Gasztroenterológia, Budapest

Otthoni parenteralis táplálás (OPT) asszociált kanülinfekció az OPT egyik legsúlyosabb szövődménye. 2010 és 2011 között centrumunkban hét beteget kezeltünk, 1000 táplálási napra számítva 0,51 katéterinfekció jutott. 2012 és 2014 között tizenegy beteget kezeltünk, a kanülinfekciós ráta 1,58 lett. Mivel a kanülinfekciós ráta növekedett, kanülmegtartási protokollt vezettünk be. Az alkalmazott protokoll: 1. azonnali katétereltávolítás gomba, Pseudomonas, MRSA vagy más rezisztens törzs által okozott infekció esetén; 2 . ismételt és igazolt kanülinfekció esetén a katéter használatát felfüggesztjük; 3. három alkalommal 70 százalékos alkohollal zárást végzünk; 4. a katéter ismételt használatát a fehérvérsejtszám és a CRP normalizálódása esetén kezdhetjük meg; 5 . ezentúl a katétert minden második táplálási napon Tauroloc-Hepával zárjuk. Megvizsgáltuk a kanülmegtartási napokat és az infekció okozta szövődményeket. Három betegünknél jelentkezett visszatérő kanülinfekció, kettőnek van közülük jejunostomája és egynek van ismert tumoros betegsége. Átlagéletkor: 51 év. Beteg-1: Háromszor E. coli okozta kanülinfekció, harmadik alkalommal a kanül cseréjére került sor, szövődményt nem észleltünk. Katétermegőrzés: 112 nap. Beteg-2: Egy alkalommal coag.neg. Staph. fertőzés. Katétermegőrzés: 65 nap. Beteg-3: Enterococcus fecalis, Klebsiella-pneumonia, majd caog. neg. Staph. fertőzés. Katétermegőrzés: 179 nap. Kanülinfekciós ráta ebben a csoportban 3,95. A három eset közül kettőnél szövődményt nem észleltünk; a katétercsere idejét átlagosan 118,7 nappal lehetett kitolni. Egy tumorral és jejunostomával élő betegnél a harmadik alkalommal ismétlődő kanülinfekció szövődményekén endocarditis alakult ki. Vizsgálatunk alapján a férfi nem és a >450 napon át alkalmazott OPT magasabb rizikónak számít, ezt a szakirodalom is alátámasztja. Megváltoztattuk protokollunkat: amennyiben a második igazolt, ismétlődő kanülinfekció kialakul, a katétert eltávolítjuk. 